
\title{
Britain seeks compromise on animal research
}

\section{Laura Nelson, London}

Attacks on facilities, assaults on lab staff and a distinct lack of public support have combined to make animal research a significant problem for the British government.

On the one hand, it wants to support biomedical research and bolster the pharmaceutical industry, Britain's most successful high-technology sector. But by doing so it might alienate a public that is largely ambivalent about the value of animal experiments.

The government is expected to try to resolve this dilemma shortly by announcing a set of measures to secure the future use of animals in research. The plan is likely to involve improving conditions for lab animals, reducing the number used in experiments and investigating alternative approaches.

Concern about animal welfare has deep roots in Britain. The Royal Society for the Prevention of Cruelty to Animals, for example, is like a national institution - last year, it was supported by more than 300,000 donors and spent some $\mathfrak{E} 80$ million (US\$140 million) on animal-welfare activities.

"The United Kingdom has always had a greater concern than most about animal welfare," says Mark Matfield, director of the Research Defence Society (RDS), a lobby group that defends animal testing.

A 1999 poll commissioned by the Medical Research Council (MRC), for example, found that just over a quarter of the UK population supported animal experiments "for all types of research where there is no alternative". Nearly two-thirds could accept medical research using animals, but the same number said that they lacked trust in the current regulations.

Such concern has provided fertile ground for extremists (see below). And despite Prime Minister Tony Blair's declaration in 2002 that "we cannot have vital work stifled simply because it is controversial", pressure on UK animal research has been mounting. In January, for instance, the University of

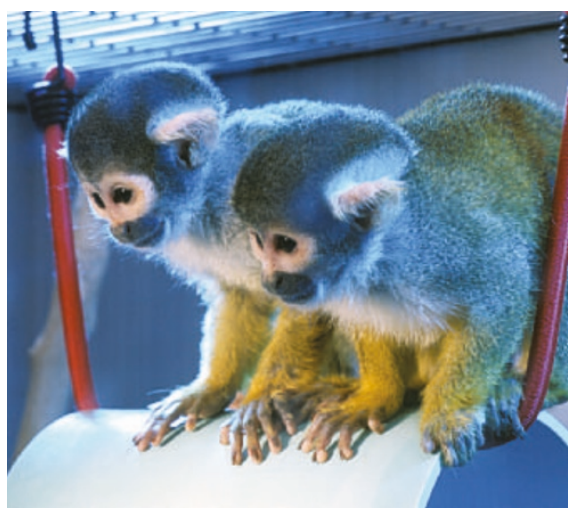

Testing times: experiments on lab animals such as these squirrel monkeys displease the public.

Cambridge scrapped plans for a primate facility for neuroscience research because of rising costs caused, in part, by animal-rights campaigners (see Nature 427, 386; 2004).

The issue was tackled by a House of Lords select committee, which issued a report on animal research in July 2002. The committee recommended far stronger government support for the 'three Rs': replacement, reduction and refinement of animal experimentation. The new measures are the government's attempt to follow through on these recommendations.

Details of the plan are under tight wraps, but some observers predict that the government will set up a 'virtual centre' to lend impe-

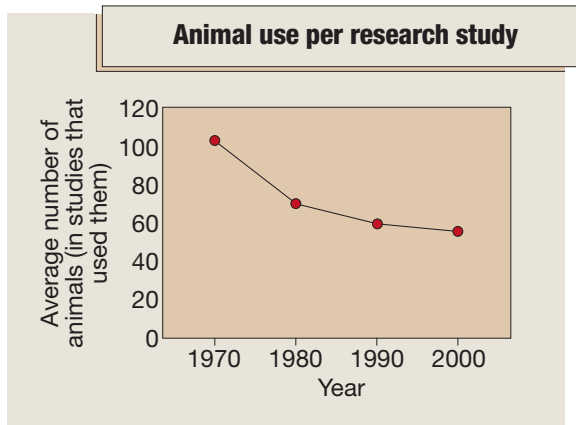

tus to the three Rs. They also expect additional funds for research into each of the three strands; last year, the Home Office allocated

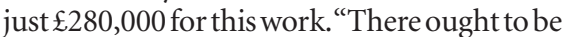
more," says Donald Broom, an animal-welfare researcher at the University of Cambridge and a member of the Animal Procedures Committee, which advises the government on the current research programme.

Research agencies have already taken steps to improve the way in which animal research is done. In 2001, for example, the MRC set up the Centre for Best Practice for Animals in Research in London to implement the three Rs. "We have an obligation to refine procedures wherever possible," says Vicky Robinson, head of the centre.

Critics say that the MRC has moved too slowly. Gill Langley, a zoologist and scientific adviser to the Hitchen-based Dr Hadwen Trust, which funds research using alternatives to animals, says that the best practice centre has consistently emphasized reduction and refinement, but not replacement. She brands its work "a smokescreen".

But available data suggest that replacement has indeed been taking place, not just in Britain but around the world. This month, for example, Hans-Erik Carlsson, a physiologist at Uppsala University in Sweden, published an analysis of lab animals used in experiments. He looked at 2,800 scientific articles published in major biomedical journals between 1970 and 2000 (H.-E. Carlsson, J. Hagelin and J. Hau Vet. Rec. 154, 467-470; 2004). Although the number of articles published more than doubled in this period, the proportion of them using animals fell by almost one-third. In the studies that did use animals, the average number used also fell by nearly a half (see right).

But in Britain, progress needs to continue if public pressure to curtail animal research is to be eased. "There is pressure on the government to do something," says Barbara Davies, communications director at the RDS.

\section{Victims of extremists join together to change the law}

\section{Laura Nelson, London}

Scientists and technicians who are harassed or assaulted because of their links with animal research now have a collective voice.

Launched in London on 22 April, Victims of Animal Rights Extremism (VARE) aims to provide a support network for its members. It has no money and will not be registered as a charity because most of its members are reluctant to reveal their identities for fear of further harassment.

Clive Page, a pharmacologist at King's College London who works on asthma and lung disease, is one VARE member who has gone public. "Most people are not going to put their heads above the parapet if they think the activists are going to murder them," says Page, who was listed in 1999 as a potential assassination target on a website put up by militant opponents of vivisection.

VARE says it wants to see legislation specifically to deal with the prosecution of criminal activity by animal-rights groups.

Some groups opposed to animal experiments dismissed the association as a front for the drug industry. "This is an attempt by the pro-vivisection lobby to exploit the issue of animal-rights extremism in order to gain public sympathy," says Wendy Higgins, campaigns director for the British
Union for the Abolition of Vivisection.

But victims of animal-rights extremism say that they need to join together for support and advice. Mark Matfield, director of the Research Defence Society, a pressure group that defends animal testing, says that between 20 and 30 activists are responsible for most criminal activity - and that the police know who they are. "Criminal law is not giving enough protection," he says.

A spokeswoman for the Home Office says that the government is "determined to tackle animal-rights extremists and to support the biotechnology industry".

www.vare.org.uk 